\title{
Understanding the University and Faculty Investment in Implementing High-Impact Educational Practices
}

\author{
Allison White \\ Ohio University \\ whitea3@ohio.edu
}

\begin{abstract}
A variety of assessment options that incorporate high-impact educational practices (HIPS) have emerged to assist higher education faculty in meeting student learning outcomes. HIPS are teaching and learning tools which have been demonstrated to increase student engagement and persistence. Practices such as first-year seminars, tech-rich learning communities, collaborative projects, undergraduate research, service learning, practicums, and internships are meaningful educational tools used to assess/measure a student's cumulative learning at various intervals. However, utilization of these practices is not often applied systematically due in part to the required investment of time, training, and money. This paper describes HIPS that support course and program-level learning outcomes in conjunction with the required investments for implementation of each. An exploration into why these types of practices are critical to student learning and success unveils which students have access to these opportunities. Findings emphasize the value of investing in these practices for all students in order to ensure student success, satisfy university accreditation standards, and meet the current mandates of our government's "completion agenda" which is geared towards preparing America's future workforce.
\end{abstract}

Keywords: Higher education, assessment, learning outcomes, high-impact practices, faculty development

When designing degree programs and courses, higher education faculty set educational goals for students that begin with learning outcomes at the program and course levels. Meeting those learning outcomes in today's college classroom should include active learning and a variety of meaningful assessment tools and methods (Association of American Colleges \& Universities [AAC\&U], 2015). However, in practice, meeting these goals can be influenced by many factors with a predominately negative influence coming from the amount of faculty time and training required in addition to budget constraints.

Asking degree program coordinators about their level of involvement and what decisions were made about courses or entire programs in the past year is one way to enhance goal setting. To support budgetary decision making and investment concerns, it is important to know what evidence was used to support those decisions and what influence on a course or program was intended with those decisions. Although instructors do not always articulate an end result in advance, this is the process of outcomes-based assessment and the development of competencies (Leutner, Fleischer, Grünkorn, \& Klieme, 2017). The desire to meet these learning outcomes is there, but are institutions investing in high-impact educational practices (HIPS)? If so, are the investments being utilized in a meaningful way in practice?

Since the mid-1990s, the importance of active learning in higher education has been steadily increasing as the shift from lecture-based courses to actually producing learning has 
evolved to include evidenced-based assessment (AAC\&U, 2015). Assessment practices are also becoming more complex and often vary from the traditional test or basic exam to more meaningful ways to measure student learning (Kuh, 2008). However, implementation of these practices and assessments comes at a cost. Workforce development in conjunction with the completion of licensure, certification, and degree programs is at the forefront of requirements from governmental funding models for public colleges and universities (United States Department of Education, 2011). Findings will prove that if institutions and faculty are not investing in HIPS, retention and completion suffer which may result in a loss of state funding. The purpose of this research is to demonstrate the importance of the investment in HIPS as a primary factor in today's educational funding environment and to encourage policymakers, institutional leadership, and faculty to incorporate meaningful and measureable assessments through HIPS by balancing the required investment of time, training, and money.

Beginning with a background on assessment and then moving through a description of various assessments of student learning using HIPS, methods such as first-year seminars, tech-rich learning communities, collaborative projects, undergraduate research, global/diversity learning, service learning, practicums, and internships are explained. The ability to use HIPS and then measure the impact on a student's cumulative learning is examined. To establish a basis for the implementation of HIPS, the professorial viewpoint is included in a discussion about the development of outcomes and assessments. Next, the investment in HIPS is factored into the use of active learning practices, as an unsystematic approach is evident in many programs and across campuses often with good reason. The required investment of time and money and sometimes faculty training is explained in addition to factors for faculty buy-in and involvement.

Finally, exploration into why these types of HIPS are effective and which students have access to them emphasizes the need for this investment and explains why some students are not exposed. The paper concludes with the mandates of the "completion agenda" which are geared towards preparing America's workforce but are also emphasizing the need for active learning, guidelines for learning outcomes across the curriculum, and high-impact assessment (United States Department of Education, 2011). Institutions and their state governments need to work together to prioritize on-time graduation (Complete College America, 2013).

\section{Background on Assessment and Investment}

Sackett, Schmitt, Ellingson, and Kabin (2001) confirmed that testing for knowledge, skill levels, and abilities often contributes to the decision-making process for jobs and education placement. Users of such tests like employers or educators often face difficult choices when trying to optimize the performance of chosen individuals, and selection of materials that assess the full range of relevant attributes is important (Sackett, et al., 2001). Assessment should be meaningful (expert driven) and manageable, taking into account varying resources (Bresciani, 2015). Barr and Tagg (1995) recognized the shift from the traditional, dominant teaching and "Instruction Paradigm" to the "Learning Paradigm" which focuses the college's purpose to produce learning using a variety of means. They also recognized that with this shift comes an increase in cost (Barr \& Tagg). It is difficult to increase outputs without increasing resources. Quality is threatened without support for teaching; yet budgets have remained stable or declined (Barr \& Tagg). According to Shumway and Harden (2003), factors of validity, reliability, impact on learning, and practicality including cost should be taken into account when instruments are chosen to assess learning outcomes.

Journal of the Scholarship of Teaching and Learning, Vol. 18, No. 2, June 2018.

josotl.indiana.edu 
Unfortunately, researchers offer many examples of practices that can become cost prohibitive. For example, first-year seminars and experiences often include a research component; however, undergraduate research in a course or degree program can be costly as the investment varies based on the intensity of each instance and the ability to present or compete with the research results (Kuh, 2008). In addition, students often conduct research projects under the supervision of faculty or with faculty at the graduate level which can incur costs, but there are few opportunities at the two-year level where obtaining funds can be an issue (Kuh, 2008).

Other examples of HIPS that can become costly are practicums and internships, which involve often unforeseen and unplanned costs to students, employers, and universities. In a study at Northwestern University (2015), researchers found that many universities have required fees for internship courses, and the cost to students can be phenomenal especially when good opportunities come in the summer when students do not typically receive financial aid dollars to enroll in internship courses. Adding to this, some companies exploit student workers with unpaid labor, although it is illegal for a student's work to provide an immediate advantage to the employer (Northwestern University, 2015). Still, grant monies can assist students, and federally funded internships can provide work-study dollars to student interns (Northwestern University, 2015).

An acknowledgment of the costs associated with the implementation of high-impact practices is found in the University System of Maine's (USM) Title III High-Impact Educational Practices grant offering (USM, 2013). USM offers \$500 to their institutions to support communitybased experiential learning/field trips, supplies, materials, training and development (for faculty and students), speakers, student workers, learning communities/collaborative learning, and software/web-based resources (USM, 2013). As state budgets continue to tighten funding to education, making the dollars stretch is vitally important.

\section{Active Learning Practices and Assessments}

It is not only important to have assessments that assist in meeting accreditation requirements, model best practices, and meet national benchmarks, but it is also critical to meet student needs beyond the college experience; traditional test and exams meet this criterion at minimum (Dowling, Godfrey, \& Gyles, 2003). Wiggins (2014) posits that if a program's goals are to provide students with opportunities to develop their leadership skills, how does a standardized test or basic, objective final exam measure that skill? It does not, and there are a variety of reasons why instructors in higher education continue to use tests and exams versus other assessment methods (Wiggins, 2014). Reasons include lack of time, lack of knowledge regarding other methods, lack of funds, and miscommunication about what actually constitutes an appropriate, measureable assessment of course goals (Wiggins, 2014). Understanding these practices and their importance is key to turning this challenge around to meet outcome goals.

Going beyond the traditional quiz, test, midterm, or final exam involves the inclusion of other assessments of student learning as found in first-year seminars, learning communities, collaborative projects, undergraduate research, global/diversity learning, service learning, practicums, and internships (AAC\&U, 2015). A student's individual effort and involvement is critical in determining the impact of college; institutions encourage student engagement by focusing on ways to shape academic, interpersonal, and extracurricular offerings (Pascarella \& Terenzini, 2005). The Association of American Colleges and Universities supports the teaching and learning practices listed below as being widely tested and shown to be beneficial for college students from many backgrounds (AAC\&U, 2015). These practices take many different forms,

Journal of the Scholarship of Teaching and Learning, Vol. 18, No. 2, June 2018.

josotl.indiana.edu 
depending on learner characteristics and on institutional priorities, budgets, faculty, and contexts, yet some universities have still been able to link these practices to students' cumulative learning (Kuh, 2008). Unfortunately, on almost all campuses in an AAC\&U study, utilization of active learning practices is unsystematic, often to the detriment of student learning (Kuh, 2008).

Below are brief descriptions of the high-impact practices that Kuh's (2008) research suggests increases rates of student retention and student engagement while providing more meaningful ways to assess learning and measure outcomes.

First-Year Seminars and Experiences: Many schools now build into the curriculum firstyear seminars or other programs that bring small groups of students together with faculty or staff on a regular basis. The highest-quality first-year experiences place a strong emphasis on critical inquiry, frequent writing, information literacy, collaborative learning, and other skills that develop students' intellectual and practical competencies.

Common Intellectual Experiences: The older idea of a "core" curriculum has evolved into a variety of modern forms such as a set of required common courses or a vertically organized general education program that includes advanced integrative studies and/or required participation in a learning community.

Learning Communities: The key goals for learning communities are to encourage integration of learning across courses and to involve students with "big questions" that matter beyond the classroom.

Writing-Intensive Courses: These courses emphasize writing at all levels of instruction and across the curriculum, including final-year projects. Students are encouraged to produce and revise various forms of writing for different audiences in different disciplines.

Collaborative Assignments and Projects: Collaborative learning combines two key goals: learning to work and solve problems in the company of others and sharpening one's own understanding by listening seriously to the insights of others, especially those with different backgrounds and life experiences.

Undergraduate Research: Many colleges and universities are now providing research experiences for students in all disciplines. Undergraduate research, however, has been most prominently used in science disciplines.

Diversity/Global Learning: Many colleges and universities now emphasize courses and programs that help students explore cultures, life experiences, and worldviews different from their own.

Service Learning, Community-Based Learning: In these programs, field-based "experiential learning" with community partners is an instructional strategy - and often a required part of the course. The idea is to give students direct experience with issues they are studying in the curriculum and with ongoing efforts to analyze and solve problems in the community. A key element in these programs is the opportunity students have to both 
apply what they are learning in real-world settings and reflect in a classroom setting on their service experiences.

Internships: Internships are another increasingly common form of experiential learning. The idea is to provide students with direct experience in a work setting - usually related to their career interests - and to give them the benefit of supervision and coaching from professionals in the field.

Capstone Courses and Projects: Whether they're called "senior capstones" or some other name, these culminating experiences require students nearing the end of their college years to create a project of some sort that integrates and applies what they've learned. The project might be a research paper, a performance, a portfolio of "best work," or an exhibit of artwork. (Kuh, p. 14-15).

These types of high-impact educational practices are effective when students have access to them. According to Bresciani (2015), program goals often include providing students with opportunities to develop their communication skills, but other than classroom presentations the best way to measure interpersonal and communications skills is through community-based learning such as interviewing professionals, volunteering, practicums, and internships. Still, there are cost factors involved that interfere with access. Travel for students to these locations is one such impediment. Programs in states such as Ohio with internship grant opportunities can help to relieve some of this burden (Ohio Higher Ed, 2014).

\section{University Accreditation and Program Assessment}

University accrediting bodies are focused on academic assessment at every level from individual course assessments to program level assessments. Kirkpatrick's (2009) New World Model contains four levels of learning evaluation in a widely known model used to analyze and evaluate the results of training and educational programs. In this model, level one is reaction measuring how participants react to the training. Level 2 is learning which analyzes if students truly understood and increased their knowledge, skills, or experience. Level 3 looks at behavior to see if students are utilizing learned skills at work and if there are any changes in behaviors. Finally, level 4 determines if the course material presented had a positive impact and produced results (Kirkpatrick, 2009).

The implementation of HIPS in a degree program can support efforts to assess programlevel learning outcomes. Practices like certification preparation, field trips, and community involvement can follow Kirkpatrick's level one by measuring to what degree students react favorably to coursework as demonstrated in certification testing, field trip responses, and community involvement (Kirkpatrick, 2009). Learning can be measured in level 2 to assess knowledge, skills, attitudes, confidence, and commitment based on a student's participation in degree program projects, capstone projects, portfolios, and grading of portfolios or written work required across the curriculum. Behavior can be measured in level 3 to evaluate the application of learned skills as applied in internships. Finally, in level 4 results can measure targeted outcomes as a result of evaluations by internship site supervisors (Kirkpatrick, 2009).

Journal of the Scholarship of Teaching and Learning, Vol. 18, No. 2, June 2018.

josotl.indiana.edu 
White

\section{The Cost Factors of Implementation}

The inputs of money and time are vital to any course and program success; the focus here is monetary although the impact for actual implementation often involves significant amounts of time required by faculty which should not be ignored (Allred, Gridley, Larsen, \& Mathie, 2013). Although exact costs for specific iterations of high-impact practices are difficult to calculate or pull from budgets, nothing makes the high cost more obvious than the efforts of donors to the cause. In 2011, the Bill \& Melinda Gates Foundation and the Lumina Foundation offered "generous funding" to a large-scale research and practice-improvement initiative focused on identifying and promoting high-impact educational practices in community colleges (Center for Community College Student Engagement, 2014). A closer look at budgets, faculty structures, and cost definitions may explain more of the cost factors of implementation.

\section{Budget Concerns}

A look at today's budget concerns in higher education and the subsequent changes to the faculty structure further explain the struggle for implementation of high-impact learning practices. In Ohio, state representatives are enforcing a tuition freeze in conjunction with rewards for higher graduation rates; this message is mixed (Perkins, 2015). Their goal is to raise graduation rates and increase workforce readiness (Governor's Office of Workforce Transformation, 2015). However, workforce readiness may be difficult to attain without support for high-impact learning outcomes with activity-based learning and quality assessments.

According to Woodhouse (2012), complications of the change from a quarter's system to a semester's system left Ohio's universities struggling. In 2012, Ohio State University went from offering courses in quarters to offering courses in a semester system and in doing so changed its general education requirements (Woodhouse, 2015). The change precipitated a 12 percent decline in credit hour enrollment at the College of Arts and Sciences, compared to an 8 percent decline for Ohio State as a whole (Woodhouse, 2015). These cuts to universities trickle down to degree program budgets and budget items like libraries and software. It also raises the question of which students have access to high-impact practices. Underserved populations (defined as firstgeneration, minority, transfer, and low-income students) miss these opportunities, and funding is one key factor (Finley \& McNair, 2013).

\section{Faculty Structure Changes}

Under the "Instruction Paradigm", Barr and Tagg (1995) reported that colleges suffer from a serious design flaw in structure, which prohibits any increase in productivity without the risk of diminishing the quality of the product. Productivity is defined as cost per hour of instruction per student (Barr \& Tagg, 1995). In this view, the very quality of teaching and learning is threatened by any increase in the student-to-faculty ratio (Barr \& Tagg, 1995). With the majority of faculty who are teaching being part-time or on yearly contracts versus full-time and tenure track, the challenges for quality practices continue (McNair \& Albertine, 2012).

Journal of the Scholarship of Teaching and Learning, Vol. 18, No. 2, June 2018.

josotl.indiana.edu 
White

\section{Defining Cost}

Under the "Learning Paradigm”, Barr and Tagg (1995) noted that productivity is redefined as the cost per unit of learning per student. Under this new definition, however, it is possible to increase outcomes without increasing costs. Barr and Tagg's (1995) findings support that alternatives to the traditional semester-length and classroom-based lecture methods produce more learning. Some of these alternatives are less expensive; many produce more learning for the same cost (Barr \& Tagg, 1995). Under this paradigm, producing more with less becomes possible because the 'more' that is being produced is learning and not hours of instruction; productivity, in this sense, cannot even be measured in the "Instruction Paradigm" because all that exists is a measure of exposure to instruction (Barr \& Tagg, 1995).

The reason for this lack of outcomes knowledge is profoundly simple: under the "Instruction Paradigm”, student outcomes are simply irrelevant to the successful functioning and funding of a college (Barr \& Tagg, 1995). The faculty evaluation systems, for example, evaluate the performance of faculty in teaching terms, not learning terms. An instructor is typically evaluated by peers or a dean on the basis of whether lectures are organized, whether the appropriate material is covered, whether interest in and understanding of the subject matter is shown, whether preparation for class is demonstrated, and whether respect for students' needs is obvious (Barr \& Tagg). All these factors evaluate the instructor's performance in teaching terms, and they do not raise the issue of whether students are learning, let alone demand evidence of learning or provide for its reward (Barr \& Tagg).

Institutional leaders may protest that HIPS are labor-intensive and therefore costly, still concerns about cost need to be addressed in a larger context (Kuh, 2008). In our demanding, increasingly competitive global environment, the quality of learning has become our most important societal resource (Kuh, 2008). According to Kuh (2008), if students leave college without the preparation they need, the long-term cost to them and to our society will be devastating. Conversely, if HIPS support both student persistence and heightened achievement on essential learning outcomes, then leaders will find the monies to make them a top priority (Kuh, 2008).

\section{High-Impact Practices - An Example}

Descriptions of high-impact educational practices are provided from an associate in applied business degree program (OUC, 2017). The program coordinator's high-impact practices demonstrate limits to inclusion yet show measurable productivity in practices that can be implemented at low or no cost. This example, from this author's experience as an associate professor and program coordinator for a program in applied business, demonstrates the costs and balances necessary to put these educational practices into place on a regional campus of a public university. It should be noted that this program employs one full-time, tenured associate professor, one retired 1/3 option professor emeritus, and five part-time instructors (OUC, 2017).

Mentoring is an important factor for student support. This program utilizes first-year experiences such as an entry/exit seminar offered in the fall; students in this course experience class time with graduating students (OUC, 2017). These experiences promote a mentoring environment where, among many interactions, the entry students present career research and exit students share capstone projects to the combined group. Topics of a small and large scale were discussed, students volunteered in the community, and field trips to large businesses occurred in three of the last four years. Faculty from baccalaureate programs and career services staff have

Journal of the Scholarship of Teaching and Learning, Vol. 18, No. 2, June 2018. josotl.indiana.edu 
spoken to the class on topics of furthering their education and career preparation (OUC, 2017). Many programs see the value in mentoring. Mentoring from multiple levels has been shown to allow STEM undergraduate majors to excel in their programs leading to increased retention and graduation rates (Wilson, Holmes, deGravelles, Sylvain, Batiste, Johnson, McGuire, Pang, \& Warner, 2011).

Another example of high-impact assessment is the program's practicum option and internship requirement (OUC, 2017). Students in the major who desire a job shadowing experience or the opportunity to work with a professional in the community for a course project enroll in the optional practicum course. Student interns apply for positions in the community with the opportunity to apply learned skills in a working environment. Application of learned skills leading to assessment by the employer is the key to this required practice (OUC, 2017).

External certification assessments from organizations outside of the university offer the perfect example of the impact of cost to this program (OUC, 2017). Students study Microsoft Office productivity applications. The materials for the course are aligned with preparation for the Microsoft Office Specialist (MOS) certifications in five areas (Microsoft, 2015). Practice test and certification exam licenses cost thousands of dollars and are outside of the program's yearly budget. In the past, the campus budget has allowed for the purchase of licenses. Today, the budget cannot stretch for this purchase and the alternatives under consideration are course fees, coordination with local vocational programs, and exploration of the campus as a regional testing center (OUC, 2017). Since the testing center option would incorporate testing in many areas and certification of the campus as a site, this has required input from multiple parties outside of the original program. An investment of time and likely dollars is necessary at this step. Currently, students are encouraged to seek testing sites at their personal expense (OUC, 2017). Similarly, nursing programs are seeking partnerships with healthcare organizations to minimize the cost of NCLEX-RN testing and repeat testing (Roa, Shipman, Hooten, \& Carter, 2011). The completion agenda will continue to drive this issue towards a solution.

A crucial element beyond these costs, examples, and recommendations is each faculty member's personal motivation to provide an educational experience for all students that will inspire creativity, stimulate problem solving, and foster a level of engagement that transcends the classroom and fosters lifelong learning (McNair \& Albertine, 2012). The development and delivery of high-quality high-impact practices and subsequent assessments is dependent upon both institutional support and faculty willingness.

\section{Discussion}

Various perspectives on the assessment movement and learning versus instruction must be understood and implemented in a cost-effective manner (Barr \& Tagg, 1995). While this movement has been under way for at least a decade, it has not infiltrated into normal practice due to the dominance of the lecture-based practice especially in the science classrooms (Barr \& Tagg, 1995; Tanner \& Allen, 2004). Only a few colleges across the country systematically assess student learning outcomes; however, educators in California community colleges have learned that 45 percent of first-time fall students did not return in the spring with many students averaging six years to earn an associate degree (Barr \& Tagg, 1995). DeAngelo, Franke, Hurtado, Pryor, and Tran (2011) studied completion rates for first-time, full-time students at four-year institutions and found that less than four out of every ten students (38.9 percent) were completing a degree in four years of college. As the likelihood of degree completion begins to diminish, only 56.4 percent of

Journal of the Scholarship of Teaching and Learning, Vol. 18, No. 2, June 2018.

josotl.indiana.edu 
White

students finish in five years and 61.2 percent earn a bachelor's degree after six years (DeAngelo, et al., 2011). Considering these numbers, should lecture-based practice continue?

Many institutions construe teaching almost entirely in terms of lecturing (Barr \& Tagg,

1995). A true story makes the point:

A biology instructor was experimenting with collaborative methods of instruction in his beginning biology classes. One day his dean came for a site visit, slipping into the back of the room. The room was a hubbub of activity. Students were discussing material enthusiastically in small groups spread out across the room; the instructor would observe each group for a few minutes, sometimes making a comment, sometimes just nodding approval. After 15 minutes or so the dean approached the instructor and said, "I came today to do your evaluation. I'll come back another time when you're teaching” (p. 20).

Exploration into why these types of practices are effective and which students have access to them emphasizes the need for the investment into high-impact practices including spreading the message, as the mandates from the U.S. government's “completion agenda” are geared toward preparing America’s workforce (United States Department of Education, 2011).

\section{The Completion Agenda}

Former President Obama's American Graduation Initiative and 2020 college degree completion agenda focused on building a more highly-skilled and productive workforce; more students completing a college degree in four years or less was the proposed method to meet his goal (United States Department of Education, 2011). In 2013, the national on-time completion rate was at 19 percent for students seeking four-year degrees, and state governments along with other organizations became more involved (Complete College America, 2013).

In April 2010, the American Association of Community Colleges (AACC) joined with five other national organizations to express a shared commitment to student completion (Ohio Higher Ed, 2015). These partner organizations (the Association for Community College Trustees, the Center for Community College Student Engagement, the League for Innovation in the Community College, the National Institute for Staff and Organizational Development, and the Phi Theta Kappa Honor Society) participated in an unprecedented joint-signing ceremony that committed the organizations to assisting members in producing 50 percent more students with high-quality degrees and certificates by 2020 (Ohio Higher Ed, 2015). It is time to expand this commitment beyond our organizations to our campuses (McPhail, 2011).

This agenda is further emphasized in the state of Ohio where the Board of Regents has implemented College Credit Plus and other initiatives. College Credit Plus provides students from sixth to twelfth grade the opportunity to earn college credits while completing high school credits at the same time (Ohio Higher Ed, 2015). The Complete College Ohio Task Force Report \& Recommendations paper identified an array of policies, practices, and programs for improving students' college readiness, reducing the time it takes for students to attain a certificate or degree, and incentivizing progress and completion (Ohio Higher Ed, 2015).

Policies aimed at encouraging institutions to produce more graduates by creating a funding model to encourage on-time graduation are described as performance-based funding (Hillman, Tandberg, \& Fryar, 2015). In 2007, Washington implemented the Student Achievement Initiative, which was a statewide performance accountability system designed to improve retention and

Journal of the Scholarship of Teaching and Learning, Vol. 18, No. 2, June 2018. josotl.indiana.edu 
degree attainment for community colleges (Hillman, Tandberg, \& Fryar, 2015). In the end, this emphasis on completion and attainment must also include HIPS as part of budgetary and academic decision making and certainly not hinder these practices with budget constraints.

\section{The Professorial Viewpoint - Outcomes and Assessment}

From this professor's viewpoint, full-time faculty are the primary decision makers in the development of course materials, and they have research means to determine outcomes and the implementation of assessment. The establishment of learning outcomes and a matching, measurable assessment is the key to understanding the need for active learning and high-impact educational practices involving assessment beyond the traditional objective, multiple-choice examination. The following is a description of the development of outcomes, assessments in practice, and faculty development from this viewpoint.

Development of outcomes. In brief, developing program outcomes and subsequently course outcomes is an evidenced-based process requiring expert input. Appropriate verbs are chosen from a theoretical approach to delineate the level of expectation of learning outcomes based on best practice evidence. Standards are used for the selection of the appropriate verbs to match levels of learning. The most important part of this course development process is the selection of activities, assignments, and assessments that match these verbs. Often a standard test or exam does not match the expectation as set by the verb and does not fully assess student learning. This is the point where faculty must wisely implement HIPS and assessments.

Assessment in practice. In practice, writing across the curriculum including the opportunity for undergraduate students to conduct relevant research is often overlooked when describing assessment even if it is implemented. When asked how they assess students, professors reply that a midterm and final examination are their primary tools without giving proper weight to other assignments such as research, portfolios, and other written works. The professor may make a writing assignment without giving it the rigor required for research excellence that will prepare the student for future writing. This rigor could include collaboration with other students, interviewing within the community, understanding of writing standards for formatting, and presentation of findings. In this example, writing does not appear to require much in the way of training, but the commitment of time is evident.

Barr and Tagg (1995) reported locating professors, commissions, and task forces who lacked vision, and they witnessed these reformers advocate for many of the new "Learning Paradigms" yet only a few of them were widely adopted. The reason is that they have been applied sparsely within the structures of a dominant paradigm that rejects or distorts them, thus the efforts have often failed (Barr \& Tagg, 1995). For example, if students are not learning to solve problems or think critically, the old logic, according to Barr and Tagg dictated faculty must teach a class in creative thinking and make it a general education requirement for degree completion (Barr \& Tagg, 1995). The logic is all too circular: What students are learning in the classroom does not address their needs or that of the community; therefore, faculty could bring them back into another classroom and instruct them some more (Barr \& Tagg, 1995). The result is never what faculty hope for as a student learning outcome. Richard Paul, director of the Center for Critical Thinking stated that critical thinking is taught in the same way that other courses have traditionally been taught, which is with an excess of lecture and insufficient time for practice (Barr \& Tagg, 1995). It is time for professorial buy-in to the "new logic" and change.

Journal of the Scholarship of Teaching and Learning, Vol. 18, No. 2, June 2018.

josotl.indiana.edu 
Faculty Development. For implementation of high-impact practices to spread, faculty members need development and encouragement to make changes in the classroom, they need the resources to obtain the right tools and environment for developing these practices (McNair \& Albertine, 2012). Currently, the majority of faculty are teaching part-time or are on yearly contracts, which presents challenges (McNair \& Albertine). However, faculty innovators are at work across all types of colleges and universities. According to research by McNair and Albertine (2012), professional development opportunities introduce faculty (full-time and part-time) to highimpact practices, assessments, and course designs as well as individual faculty mentoring for collaborative teaching. Faculty reward structures that support innovation in the classroom, including the use of technology to facilitate collaboration, are essential elements (McNair \& Albertine, 2012). Professional development may also encourage partnerships between staff and faculty across disciplines to promote curricular and co-curricular learning throughout a student's educational experience (McNair \& Albertine, 2012).

A crucial element beyond these recommendations is each faculty member's personal motivation to provide an educational experience for all students that will inspire creativity, stimulate problem solving, and foster a level of engagement that transcends the classroom to foster lifelong learning (McNair \& Albertine, 2012). The development and delivery of high-quality, highimpact practices depends on both institutional support and faculty dedication. Motivation must come from multiple sources to enrich the professorial viewpoint. This begins with a supportive budget.

\section{Managing the Costs - Budgets That Meet Program Level Learning Outcomes - Solutions}

Preparing tomorrow's workforce is at the forefront of the completion agenda and HIPs can be the key link to providing assessments that ensure preparedness. However, it is easy to see the need for time, money, and innovative practice designs as asserted in these five elements described by Kuh (2008). First, HIPS demand that students devote considerable time and effort, which often translates into faculty availability for support. Second, HIPS help students build relationships by interacting with faculty and peers and developing mentor and advisor relationships. Third, HIPS provide students with rich feedback from supervisors including faculty, internship site supervisors, staff, and community members. Fourth, HIPS help students apply and test what they have learned (e.g. internships). Finally, HIPS provide opportunities for students to reflect in order to understand themselves and the world (Texas A\&M, 2015).

The first solution to the costs involved in implementing high-impact educational practices and assessments is to realize the value in making the investment. Program faculty leaders could continue to provide evidence to administration in support of practices with proven student successes in an effort to maximize budget dollars. According to Barr and Tagg (1995), it would make more sense to fund a college on the number of math problems students solve, for example, than to fund it on the number of students who sit in math classes. It is suspected that any system of institutional incentives based on outcomes would lead to greater learning than any system of incentives based on inputs (Barr \& Tagg).

Learning outcomes include whatever students learn and do as a result of a learning experience. Any measurement of a student's work from an educational experience is a measure of a learning outcome (Barr \& Tagg, 1995). Barr and Tagg (1995) agreed that we could count the number of pages students write, the number of books they read, their number of hours at the computer, or the number of math problems they solve, but new forms of assessment should focus

Journal of the Scholarship of Teaching and Learning, Vol. 18, No. 2, June 2018. josotl.indiana.edu 
on establishing what college and university graduates have learned, the knowledge and skill levels they have achieved, and their potential for further independent learning. One such example might be a hybrid, flexible model delivered using a combination of face-to-face seminars and electronic delivery to improve students learning in accounting programs (Dowling, Godfrey, \& Gyles, 2003).

\section{Solutions in Practice}

A few examples of actual costs and possible money saving strategies are found in the previous example from the two-year degree applied business program. In this associate degree program, first-year seminars and experiences include research. Students conducting research with faculty and group collaborations occurred only twice in a five-year period, fortunately with both resulting in conference presentations. However, faculty absorbed the travel cost personally. The program's budget covered students' conference fees at an average of \$50 per student. Compare this to the entry and exit student seminars where field trips to tour employer facilities came at a cost of \$126 per trip (transportation expenses to the university). Groups were kept small to fit the university van and the faculty pocketbook, as food was provided personally by faculty. Additionally, the employer has an investment of salaries to employees who offer the tours to students and who are unproductive during that time. The student investment in time and expenses outside of the classroom (possible loss of work hours or childcare costs) should also be considered.

Common intellectual experiences and learning communities. Stipends can be offered for faculty involved in the development of learning communities. At the minimum cost, these begin at \$500 per design at the aforementioned university. Similarly, in the associate degree program example, interdisciplinary course opportunities are offered and require additional investment of time for faculty. Faculty spend time in research, practice, and publication opportunities to prepare and inform their teaching; however, no stipend for this work is currently available.

Writing across the curriculum. Writing intensive courses in the associate degree program example included writing across the curriculum in a variety of ways. For example, students communicate with output from learned software applications. The university provided production software for students to communicate via documents, spreadsheets, presentations, diagrams, desktop publications, and email. A reduced rate for education institutions is provided by the vendor with constraints on the licenses and regular renewal requirements.

Projects and collaborative assignments. No measurable cost options for collaborative assignments and projects existed in this program. Projects throughout the curriculum provided additional opportunities for students to engage in groups and with the community. However, hidden costs to students seeking community involvement as well as library materials costs are a factor. One solution to the high cost of materials for a particular course in medical coding was the combination of the course with a practicum experience. This allowed the student to use materials provided by the practicum placement facility in conjunction with a mentor to aid in the understanding of the coding in practice.

Diversity and global learning. In addressing opportunities for diversity and global learning, the program offered an option in the general education requirement of communications studies. Currently, students in this program can substitute a general education course in public speaking for a cross-culture communications course from the same department. Other core courses have learning outcomes to address diversity and international, global perspectives as related to teleconferencing, business, and ethics. Assessment practices for these core courses includes expert interviews, facility tours, and projects. Vitally important to the success of diversity and global

Journal of the Scholarship of Teaching and Learning, Vol. 18, No. 2, June 2018. josotl.indiana.edu 
learning for this program was the students being able to access student clubs, university activities, and most importantly a diverse faculty.

Service learning, practicums, and internships. Practicums and internships can vary as to personal costs to students and faculty (site visits). With coordination from the faculty and career support staff, employers and students often receive grant dollars to support their efforts.

For this program capstone courses and projects are addressed as previously mentioned in an entry and exit seminar format. Students create non-linear portfolios of their degree program coursework and experiences. These projects are presented to the class and prepared for publication to future degree programs or employers. No formal service learning experience is provided by this degree program.

\section{A Final Argument for Inclusion of High-Impact Educational Practices}

Arguments for inclusion of certification preparation, workforce preparedness through internships, and project-based assessments are explained below with the emphasis on how these approaches provide continuous feedback to students. An example of a university strategic plan explains implementation requirements. Having credible external certification testing preparation is crucial for technical programs offering a heavily weighted applications-based curriculum. Microsoft, Cisco, and Jupiter Networks rank among the top certifications required by employers for 2016 based on a survey of job postings (Tittel, 2015). Employment preparation is a driving factor for many associate degree trained students. In a 2008 national survey, employers rate less than 40 percent of workers as "well prepared" in the areas of global knowledge, self-direction, writing, critical thinking, adaptability, self-knowledge, oral communication, quantitative reasoning, social responsibility, intercultural skills, ethical judgement, and teamwork (Kuh, 2008).

Practicums and internships provide a measure to employers of student learning on the job. The privilege of shadowing and learning skills on the job provided by practicum experiences for technical programs, human services programs, and others demonstrates how these practices are essential to student success, during and after completing their programs of study. Networking in this highly-competitive job market is often overlooked, and practicums and internships provide this essential contact. In addition, the projects completed by student interns provide the evidence site supervisors/employers need to write those letters of recommendation. However, student access, especially students in two-year programs, to paid internships is minimal and expenses quickly accumulate. Transportation costs, clothing, and meals can eliminate the opportunity for many students. Programs that seek grant monies and employer/university relationships can lead to paid positions for associate degree students that might not otherwise be an option.

High-impact educational practices offer both course and program level learning outcomes' assessments including equally vital student projects, portfolios, and service learning opportunities, which can be costly in both time and money. Transportation to community projects assignments as part of a first-year seminar experience can again be costly. Software programs and materials for projects, portfolios, and e-portfolios need to be current and effective as well. Providing on-campus opportunities for students to give back is one of the most cost-effective methods of achieving the service goal. Combining efforts with other technical programs and university-wide IT departments is a great way to get access to current applications without a direct expense to a small associate degree program budget. Capstone projects using these applications can be presented to fellow students, potential employers, and future degree programs at little or no cost to students or their program.

Journal of the Scholarship of Teaching and Learning, Vol. 18, No. 2, June 2018. josotl.indiana.edu 
The importance of all of these practices is best explained as providing continuous feedback to students. Even though the structures and settings of high-impact activities differ, students typically get frequent feedback about their performance in every one of these options. Working with a faculty member on research, having a paper checked by a peer writing tutor prior to turning it in, and having one's performance evaluated by the internship supervisor are all rich with opportunities for immediate formal and informal feedback (Kuh, 2008). Because students work in close proximity to supervisors or peers, feedback is almost continuous. In addition, a National Survey of Student Engagement in 2007 provided results showing that students who receive feedback during or after working on a research project with a faculty member are more likely to report that their relationships with faculty are friendly or supportive (Kuh, 2008).

At Utah's Snow College, their strategic plan defined quality as teaching and administrative practices that are valued by advancement and the tenure process, affirmed through assessment, and aligned with discipline-specific standards established by accrediting bodies (Allred, Gridley, Larsen, \& Mathie, 2013). Quality instruction is emphasized along with supporting student services with the investment of resources; they must continually reassess the ways in which they ensure quality (Allred, et al., 2013).

The faculty who wrote the strategic plan at Snow College expressed concerns with the shift from full-time, tenure track faculty positions to part-time positions, and recognized that to enable faculty efforts workload would need to be revised (Allred, et al., 2013). Other elements of highimpact practices in Snow College's plan included possible changes to general education, including interdisciplinary and perhaps team-taught courses, as well as the implementation of high-impact practices requiring investments of faculty time and collaboration with student support staff (Allred, et al., 2013). The plan endorsed funds for faculty to pursue terminal degrees, receive sabbaticals, and to work on summer projects designed to support the development of degree programs in strategic areas. These final words support the need for implementation by stressing that faculty should be encouraged to make use of proven educational technologies (Allred et al., 2013). Snow College administrators committed to continue to weigh the benefits versus the costs of high-impact educational practices.

\section{Conclusions}

Bresciani (2015) stated that faculty do not have to assess everything every year; it is not necessary to do everything at once. One recommendation is to start with two or three learning outcomes, be flexible, and acknowledge the successful outcomes at the level of quality balanced with effectiveness (Bresciani, 2015). Other recommendations by Bresciani include the recognition of what already worked well in the classroom and the provision of assessment expertise to help faculty evaluate a program more effectively (Bresciani, 2015).

Although a goal, based on best practices and research, may be to attain levels of student learning that can prepare them for achievement on licensure and certification tests as a logical next step after graduation, the actual goal should not be to have these outside entities evaluate a university degree program. Providing expensive testing even with the support of course fees or as part of a program's budget may often be impossible and even beyond the intended scope of the university's budget for programs. Borrow examples from other institutions to modify as appropriate and partner with other institutions in the community for optimal use of budget monies. Time for implementation of high-impact educational practices and assessments must be reallocated as well. Faculty allocate time according to values and priorities. To coordinate external

Journal of the Scholarship of Teaching and Learning, Vol. 18, No. 2, June 2018. josotl.indiana.edu 
White

testing for a program may not be the best use of faculty time; however, improving and expanding assessment options is crucial to reaching the outcomes desired for students.

In summary, program faculty leaders should continue to provide evidence to administration in support of practices with proven student success in an effort to maximize budget dollars. Working with other programs to share materials and achieve outcomes through learning communities achieves the goal for students with little or no cost. Researching grant programs for funding and working with business and community leaders to support university initiatives for assessment can provide excellent funding while also serving the community needs.

Wide-scale implementation has the potential to foster significant change and improve student success, while making excellence inclusive (McNair \& Albertine, 2012). Budget constraints and buy-in issues from faculty can limit the numbers of students involved in high-impact educational practices. The time has come for higher education institutions and their faculty to make participating in high-impact activities a reality and a priority for every student.

\section{References}

Allred, D., Gridley, B., Larsen, D., \& Mathie, C. (2013). Quality instruction and student services: Snow college strategic plan white paper. Retrieved October 2016 from https://www.snow.edu/offices/president/snowvision/images/plan.pdf

Association of American Colleges \& Universities (AAC\&U). (2015). High-impact education practices. Retrieved October 2017 from https://www.aacu.org/sites/default/files/files/LEAP/hip_tables.pdf

Barr, R. B., \& Tagg, J. (1995). From teaching to learning-A new paradigm for undergraduate education. Change: The magazine of higher learning, 27(6), 12-26.

Bresciani, M. J. (2015). Assessing student learning and development. Retrieved November 2017 from

https://www.researchgate.net/publication/228740395_Assessing_student_learning_and_develop $\underline{\text { ment }}$

Center for Community College Student Engagement (CCCSE). (2014) Identifying and promoting high-impact educational practices in community colleges. Retrieved November 2015 from http://www.ccsse.org/center/initiatives/highimpact/

Complete College America. (2013). Latest numbers show on-time graduation is a myth for most college students: Complete College America calls for states to recognize "full-time” should mean students take 15 credits per semester, 30 per year. Retrieved from https://completecollege.org/article/latest-numbers-show-on-time-graduation-is-a-myth-for-mostcollege-students/

DeAngelo, L., Franke, R., Hurtado, S., Pryor, J. H., \& Tran, S. (2011). Completing college: Assessing graduation rates at four-year institutions. Los Angeles: Higher Education Research Institute, UCLA. 
White

Dowling, C., Godfrey, J. M., \& Gyles, N. (2003). Do hybrid flexible delivery teaching methods improve accounting students' learning outcomes? Accounting Education (12) 4.

Finley, A. and McNair, T. (2013). Assessing high-impact learning for underserved students.

Retrieved November 2015 from http://www.aacu.org/assessinghips.

Governor's Office of Workforce Transformation. (2015). Ohio means jobs. Retrieved December 2015 from http://workforce.ohio.gov.

Hillman, N. W., Tandberg, D. A., \& Fryar, A. H. (2015). Evaluating the impacts of "new” performance funding in higher education. Educational Evaluation and Policy Analysis, 37(4), 501-519.

Kirkpatrick, D. (2009). The new world Kirkpatrick model. Retrieved from http://www.kirkpatrickpartners.com/Our-Philosophy/The-New-World-Kirkpatrick-Model

Kuh, G. D. (2008). High-impact educational practices: What they are, who has access to them, and why they matter. Association of American Colleges and Universities Peer Review, (3), 29.

Leutner, D., Fleischer, J., Grünkorn, J., \& Klieme, E. (2017). Competence assessment in education:

An introduction. Competence Assessment in Education. Springer International Publishing.

Maki, P. L. (2012). Assessing for learning: Building a sustainable commitment across the institution. Stylus Publishing, LLC.

McNair, T. B. \& Albertine, S. (2012). Seeking high-quality, high-impact learning: The imperative of faculty development and curricular intentionality. Retrieved November 2015 from https://www.aacu.org/publications-research/periodicals/seeking-high-quality-high-impact learning-imperative-faculty

McPhail, C. J. (2011). American Association of Community Colleges (AACC). The completion agenda: A call to action. Retrieved November 2015 from https://files.eric.ed.gov/fulltext/ED532208.pdf

Microsoft. (2015). Microsoft office specialist certification. Retrieved October 2015 from https://www.microsoft.com/en-us/learning/mos-certification.aspx.

Northwestern University. (2015). Federally funded internships. Retrieved November 2015 from http://www.sesp.northwestern.edu/higher-education/tuition-financial-aid.html.

Ohio Higher Ed. (2015). Complete college Ohio. Retrieved November 2015 from https:/www.ohiohighered.org/sites/ohiohighered.org/files/uploads/completion/CCO-task-forcereport_FINAL.pdf.

Ohio Higher Ed. (2014). Ohio means internships and co-ops. Retrieved October 2015 from https://www.ohiohighered.org/omic. 
White

Ohio University Chillicothe (OUC). (2017). Office Administration Technology (OAT) associate in applied business. Retrieved November 2015 from

https://www.ohio.edu/chillicothe/academics/degreesandprograms/officeadministrationtechnology . $\mathrm{cfm}$

Pascarella, E. T., \& Terenzini, P. T. (2005). How college affects students (Vol. 2): A third decade of research. San Francisco, CA: Jossey-Bass.

Perkins, W. T. (2015) State budget freezes university tuition rates for two years. Retrieved November 2015 from http://www.thepostathens.com/news/state-budget-freezes-universitytuition-rates-for-two-years/article_624b758a-218b-11e5-bef8-8b9d4fc9b0b6.html.

Roa, M., Shipman, D., Hooten, J., \& Carter, M. (2011). The costs of NCLEX-RN failure. Nurse Education Today, 31(4), 373-377.

Sackett, P. R., Schmitt, N., Ellingson, J. E., \& Kabin, M. B. (2001). High-stakes testing in employment, credentialing, and higher education: Prospects in a post-affirmative-action world. American Psychologist, 56(4), 302-318.

Shumway, J. M., Harden, R. M. (2003). The assessment of learning outcomes for the competent and reflective physician. Medical Teacher, 25(6), 569-584.

Tanner, K., \& Allen, D. (2004). Approaches to biology teaching and learning: learning styles and the problem of instructional selection-engaging all students in science courses. Cell Biology Education, 3(4), 197-201.

Texas A\&M. (2015). High-impact practices. Retrieved November 2015 from https://comm.tamu.edu/high-impact-practices-2/.

Tittel, E. (2015) Best computer networking certifications for 2016. Retrieved November 2015 from

http://www.tomsitpro.com/articles/networking-certifications,2-208.html.

United States Department of Education (2011). College completion toolkit. Retrieved from https://obamawhitehouse.archives.gov/sites/default/files/college_completion_tool_kit.pdf

University System of Maine (USM). (2013). USM's Title III High Impact Educational Practices. Retrieved November 2015 from http://usm.maine.edu/sites/default/files/titleiii/HIP\%

20mini\%20grants\%20RFP.pdf.

Wiggins, G. (2014). Final exams vs. projects - nope, false dichotomy. Retrieved December 2015 from https://grantwiggins.wordpress.com/2014/01/01/final-exams-vs-projects-nope-falsedichotomy-a-practical-start-to-the-blog-year.

Wilson, Z. S., Holmes, L. deGravelles, K., Sylvain, M. R., Batiste, L., Johnson, M., McGuire, S.

Journal of the Scholarship of Teaching and Learning, Vol. 18, No. 2, June 2018.

josotl.indiana.edu 
White

Y., Pang, S. S., \& Warner, I. M. (2011). Hierarchical mentoring: A transformative strategy for improving diversity and retention in undergraduate STEM disciplines. Journal of Science Education and Technology, 21(1), 148-156.

Woodhouse, K. (2015). Arts and sciences deficits. Retrieved November 2015 from Inside Higher Ed.https://www.insidehighered.com/news/2015/06/04/colleges-arts-and-sciences-struggle$\underline{\text { deficits-enrollment-declines }}$

Journal of the Scholarship of Teaching and Learning, Vol. 18, No. 2, June 2018.

josotl.indiana.edu 